University of South Florida

DIGITAL COMMONS

Digital Commons @ University of

@ UNIVERSITY OF SOUTH FLORIDA

South Florida

Academic Services Faculty and Staff

Publications

Tampa Library

$5-31-2012$

\title{
The Case for a 60-Day Interlibrary Loan Lending Period
}

\author{
Kristine Jo Shrauger \\ University of Central Florida \\ LeEtta M. Schmidt \\ University of South Florida, Imschmidt@usf.edu \\ Mary Radnor \\ University of Chicago
}

Follow this and additional works at: https://digitalcommons.usf.edu/tlas_pub

Part of the Library and Information Science Commons

\section{Scholar Commons Citation}

Shrauger, Kristine Jo; Schmidt, LeEtta M.; and Radnor, Mary, "The Case for a 60-Day Interlibrary Loan Lending Period" (2012). Academic Services Faculty and Staff Publications. 175.

https://digitalcommons.usf.edu/tlas_pub/175

This Article is brought to you for free and open access by the Tampa Library at Digital Commons @ University of South Florida. It has been accepted for inclusion in Academic Services Faculty and Staff Publications by an authorized administrator of Digital Commons @ University of South Florida. For more information, please contact digitalcommons@usf.edu. 
The case for a 60 day Interlibrary Loan lending loan period ${ }^{1}$

Kristine Shrauger, University of Central Florida, Mary Radnor, Florida International University, \& LeEtta Schmidt, University of South Florida

\footnotetext{
${ }^{1}$ Notice: This is an Accepted Manuscript of an article published by Taylor \& Francis in Journal of Interlibrary Loan, Document Delivery \& Electronic Reserve in 2012, available online: http://www.tandfonline.com/openurl?genre=article\&issn=1540-3572\&volume=22\&issue=1\&spage=47
} 
Resource Sharing departments across the state and the country have differing length periods for which they loan materials via interlibrary loan. Loan periods have been based on the internal protocol of each institution and data collected over the years. Sixteen libraries in Florida have been debating the topic of standardizing a base loan period of 60 days.

The loan periods among the libraries examined, consisting of the Florida State University Libraries (SUL), some Independent Colleges and Universities of Florida (ICUF) and one community college library, were split with 9 institutions that had either a 28 or 30 day loan period and 7 institutions that had either a 45, 56 or 60 day loan period. These 16 institutions range from large academic ARL institutions to very small institutions. The number of books circulating differs greatly among the institutions as does the staffing of each interlibrary loan department. Some of the ILL operations have numerous staff dedicated solely to resource sharing, while others have one person overseeing ILL who may also have other responsibilities. Leadership among the departments varied as well. Some of these libraries have librarians that oversee resource sharing while others are operated solely by staff members.

Interlibrary Loan policies across higher academic institutions vary throughout the state of Florida. There are no consistent policies, which can add to student confusion as they transfer from one institution to another or, as in the case of some distance learners, use the library that is closest to them (Leung 2008). The more consistent and uniform interlibrary loan policies are throughout the entire interlibrary loan world, or at least in the state of Florida, the more we can provide a unified user education and provide equal service to all of our constituents (Gregory, 2003).

\section{Analyzing the concerns}

The idea of creating a unified loan period for interlibrary loan lending returnables first came about when the SUL's embarked on a system called UBorrow, which is an unmediated Aleph ILL enabled consortial borrowing system among 12 institutions. In order to launch a unified service, the libraries had to agree to a standard loan period. Two loan periods were initially discussed: 30 days or a 60 day loan period. Whether to allow recalls and the number of renewals allowed was discussed and inspired great debate. Some institutions wanted a 30 day loan period because of the no recall stipulation. Others wanted a 60 day loan period because it would align with the interlibrary loan periods at their institution. Ultimately the UBorrow Aleph ILL system made the decision to have no recalls all owed and multiple renewals. The inability to place recalls on returnables led the group to go with a 30 day loan period.

Six months after the soft opening of UBorrow, a task force began looking at unifying both the UBorrow and traditional interlibrary loan period among the SUL's and extended the conversation to some of the ICUF institutions in Florida and one community college. As the task force analyzed the idea of a unified loan period, each institution took the opportunity to review their policies and procedures regarding the issue. Do the policies and procedures in effect for the past few years (decades) still apply? Are the needs of the patrons different now than when the policy was originally created (Harris 1999)?

When reviewing the 30 versus 60 day loan issue, there were several factors were taken into consideration: 
1. Hold/recall functionality. Is it still consistent with today's needs?

2. Renewal requests. How often do patrons ask for renewals of interlibrary loan materials?

3. Overdues. Are items that are checked out via interlibrary loan with a 30 day loan period more consistently overdue versus those items that are checked out for 60 days?

4. Access. Should we be treating interlibrary loan requests with a different loan period than the normal circulation loan periods? What is fair to students at the home institution versus the borrowing institution.

5. Staffing and training. What are the staffing issues between the two different loan periods? Does one loan period support less staff intervention than another loan period?

\section{Evaluating the Concerns}

Holds/Recalls. Holds and recalls are designed so that if an item is checked out and another patron at the home institution would like to use or borrow the item, she/he can place a "hold" or "recall" on the book. When the book comes back from the current "user" it will automatically go to the person that put the hold on the item. This may also mean that the person currently in possession of the book will receive an adjusted due date and an email message asking the patron to return the book earlier than the original due date.

When a patron comes into the library and the book that they need is checked out, no matter what the due date, the patron is unhappy. The patron either assumes that the book is unavailable to them and looks for other materials or they look for other ways to acquire the book. If patrons are savvy, they may realize that they have the option of recalling the item, thus shortening the loan period, or they may approach the interlibrary loan department and ask to borrow the item from anotherinstitution. Do we allow Interlibrary Loan departments to borrow books that are checked out from their own collection? The question becomes what are the best ways to satisfy the patron's needs when the book they want is checked out? How do we provide good customer service and still serve the needs of our own patrons?

The task force discussed whether it was appropriate to be borrowing items versus placing holds on the item. The Interlibrary Loan Codefor the United States states in 2.1 that "the purpose of interlibrary loan as defined by this code is to obtain, upon request of a library user, material not available in the user's local library." Some Interlibrary Loan departments have interpreted the code to mean that if the library owned the item and it was checked out, the ILL department could not borrow the item via ILL because the material was owned by the library. Other Interlibrary Loan departments interpreted the Code by the fact that while the library did own the item, it was currently checked out and unavailable and thus, could request the checked out item via interlibrary loan. Analyzing the "High Usage by Number of Holds" report within the Aleph Circulation reports for all SULinstitutions (Florida Center for Library Automation), the occurrence of items with multiple holds among the SUL's was fairly low in comparison to the number of books that are circulated on a yearly basis. Thirty-one titles had holds placed at several of the different institutions. These titles appeared to be either textbooks or New York Bestseller books (Hallyburton 2011). Of the 11 institutions evaluated, most had a drop in the number of multiple holds submitted over the past 3 academic years. Only 1 institution showed an increase of 5 holds placed on 1 title over the three yearperiod. 
When the University of South Florida changed it's Interlibrary loan policy to allow interlibrary loan requests for currently checked out materials, the amount of hold requests made over the course of a year dropped drastically. The patron's voice could clearly be heard in the $44 \%$ decrease from 9404 in $2008 / 09$ to 5283 in 2009/10. For many patrons, an available item far away was still a more accessible option than a checked out item close to home.

In the world of hold/recalls, however, the interlibrary loan department is just another patron whose check-outs are needed by others. Those institutions in favor of a 30 day ILL loan period felt that an extension of the loan period would only make their items unavailable in the catalog for a longer time. Some felt that items that were on interlibrary loan had a far greater risk of not being returned when a recall has been placed. Even if the borrowing library acts quickly, time will be lost acquiring the book from the patron and sending the book back to the owning institution. There are often no consequences meted out between libraries, such as overdue or recall fines for interlibrary loan patrons if they do not return the book in a timely fashion.

Offering patrons the ability to request an interlibrary loan instead of placing a hold can please both the current user of the book and the requesting patron. This policy would also address the concern that an extended interlibrary loan due date removes an item from its own patrons for too long.

Renewal Requests. Whether the item is checked out via circulation or interlibrary loan, patrons like the ability to renew items if they need them for a longer time period. Graduate students and faculty typically need their materials for long periods of time while conducting research. Most circulation operations allow patrons to log into their accounts and easily renew items without staff intervention as long as the item does not have a hold/recall placed on it. Most academic institutions do not limit the amount of renewals their patrons can make on any one item in an attempt to encourage the use of their collection and the research materials. In contrast, Interlibrary Loan renewal requests require staff intervention, which can be time consuming as both the borrowing and the lending institution are involved.

Adopting a 60 day loan period, may cut down on the number of renewal requests that are initiated through the interlibrary loan system. This would be beneficial because renewal requests are time sensitive for both the patron and for the owning ILL department and the borrowing ILL department. Depending upon how their ILL system is set up, patrons must submit their renewal requests up to five days before the book is actually due. This means that the patron must plan ahead in order to submit a renewal request with any hope of favorable answer.

The University of West Florida reviewed the borrowing renewal requests that were submitted on a peak day in October 2011 in ILLiad and discovered that of the 34 renewal requests, 30 were submitted to institutions that had a 28 or 30 day loan period. Only 4 of the renewal requests were for items originally loaned for a 60 day loan period. The University of Central Florida Libraries al so analyzed requests 
submitted on a busy day in October 2011 and evaluated the 634 items that were currently checked out on the borrowing side via ILLiad and discovered that there were 111 renewals. Of those 111 renewals that had been accepted, there was equal number of 30 versus 60 initial loan periods. Only $16 \%$ of all renewal requests for borrowed material at the University of South Florida in 2010/11 were made on items that were initially loaned for over 55 days; the majority of renewal requests were placed on items loaned for 30 days or less. Florida International University received 548 renewal requests from their ILLiad patrons in 2010-2011. Of the 12,289 UBorrow requests filled between March 1, 2011 and October 1, 2011, 4890 titles have been renewed once. Only 180 requests were renewed a $2^{\text {nd }}$ time. These numbers show that the patrons requesting renewals of the interlibrary loan material would probably find their needs satisfied preemptively by a due date of 60 days.

Overdues. Overdue items are common for both Circulation and Interlibrary Loan. Dealing with overdue notices, lost books and invoices is a time consuming and costly endeavor for library staff (Farrington, 1984). Staff must spend time sending out notices regarding blocks or fines and charging $p$ atrons for long overdue books. Some institutions levy borrowing fines for overdue ILLs as a punishment for keeping the book too long. The processing of these financial transactions require more than one staff person to be involved. At larger institutions, it can involve more than one department in the library and even other departments on campus to collect a $\$ .25$ overdue fine.

Theoretically, items with shorter interlibrary loan periods are more likely to be kept overdue and thus charges. While institutions typically do not fine each other for interlibrary loan items, most ILL departments will either block patrons from using ILL until the item has been returned or will charge the patron some sort of fine. Blocking or fining a patron, could possibly create a bad image of the library in the minds of the patron (Meyers, 1999). In addition, overdue material can also damage the reputation of the library with its resource sharing colleagues. Overdues are time consuming for both circulation and interlibrary loan. The more overdues and blocks the more labor intensive the item becomes in any interlibrary loan system. Most institutions that use ILLiad as their management tool block patrons from using ILLiad until the item has been returned. The blockage feature stops the patron from submitting requests, but it also creates more work for staff who must monitor and update patron records as items are returned and accounts are settled.

On October 28, 2011, the Interlibrary Loan department at the University of Ce ntral Florida Libraries analyzed the 634 items that were in the "checked out to patrons" queue within ILLiad. Of those items that were checked out to the patrons, 86 of those requests were overdue. Of those that were overdue, the majority were from undergraduates and faculty members. Of the 86 items that were overdue, more than 31 items were more than 10 days overdues with only a few asking for a renewal. Of those overdue items, the length of loan period did not seem to be a concern as there were an equal number of items that had a 30 day loan period versus a 60 day loan period.

At the University of South Florida, of 7545 filled borrowing loan requests 241 or $3 \%$ were turned in overdue in 2010/11 year. Items that initially had due dates over 55 days made up the minority of this 
number at $16 \%$ while $46 \%$ of these overdue items had an initial due date of 30 days or less. The remaining overdue items had due dates ranging in between these two numbers.

Access for Patrons and Researchers. Interlibrary loan and document delivery services departments were designed to support the research needs of students, faculty and staff. In order to become a more research oriented facility, libraries must provide materials and access to customers for an adequate length of time to support their research endeavors. The Center for Research Libraries (CRL) has the needs of the researcher in mind when they allow their items to be checked out for 3 months. This allows adequate time for completing heavy analysis of primary resources. Farrington (1984) reports that allowing graduate students books for "a longer loan period also reduces the number of renewals the circulation staff has to process." Graduate students, faculty and researchers tend to use books for an entire academic semester. Farrington goes on to report that graduate students need large amounts of books for their research and they need them for a long amount of time.

As the libraries that developed the UBorrow service began to look toward a 60 day loan period, one concern was the impact on the number of books that would not be on the shelves. Would the number of items that would be circulating via UBorrow and interlibrary loan decimate the collection? Would there be more books

\begin{tabular}{lll}
\hline & Total \# of requests & Grad/Faculty requests \\
\hline Florida Atlantic University & 11,519 & $8,567(74 \%)$ \\
University of Florida & 16,655 & $13,878(67 \%)$ \\
University of Miami & 10,600 & $8,430(79 \%)$ \\
University of Central Florida & 20,300 & $14,327(70 \%)$ \\
University of South Florida & 13,906 & $18,012(77 \%)$ \\
University of West Florida & 3,408 & $4966(68 \%)$ \\
\hline
\end{tabular}
circulating then in the collection? In 2009-2010, the annual report at the University of West Florida had 840,125 volumes to 80,922 users of those materials. If materials were lent out for a longer loan period through resource sharing programs, would collections still be intact for the users of the home institution to use or would the collections be obliterated and al ways checked out?

According to the OCLC Borrowing Activity Overview Report for the Florida Library Information Network (FLIN) between July 2010 and June 2011, borrowing ILL units submitted and filled 250,501 returnable requests. Between those same dates, FLIN Lending Activity Overview Report stated that FLIN lending units filled 498,102 returnable requests. FLIN is comprised of 305 public, private, special, academic and $\mathrm{K}-12$ libraries throughout the state of Florida. In comparing the number of returnables to the circulation totals of 12 institutions, the number of returnables lent is equal to that of the total number of circulation events at either Florida State University Libraries or the University of Central Florida Libraries and less than the University of Florida.

\begin{tabular}{lrrr}
\hline & Circulation Event Total & & \\
\hline & $2010 / 2011$ & $2009 / 2010$ & $2008 / 2009$ \\
\hline Florida A\&M University & 50,002 & 55,279 & $2007 / 2008$ \\
\hline Florida Atlantic University & 190,024 & 187,579 & 17,112 \\
\hline Florida Gulf Coast University & 46,684 & 43,266 & 42,165 \\
\hline Florida International University & 385,408 & 335,533 & 364,062 \\
\hline Florida State University & 525,861 & 431,831 & 426,691 \\
\hline New College of Florida & 25,419 & 26,989 & 28,159 \\
\hline University of Central Florida & 420,966 & 435,025 & 427,094 \\
\hline University of Florida & 785,841 & 856,092 & 883,407 \\
\hline University of North Florida & 198,380 & 190,280 & 212,573 \\
\hline University of South Florida & 405,010 & 428,081 & 407,018 \\
\hline
\end{tabular}




\begin{tabular}{llr}
\hline University of West Florida & \multicolumn{2}{c}{82,794} \\
\cline { 2 - 3 } & \multicolumn{2}{c}{$\begin{array}{c}\text { Collection Size } \\
\text { (as of January 18, 2012) }\end{array}$} \\
\cline { 2 - 3 } & \multicolumn{2}{c}{ Florida A\&M University } \\
& Florida Atlantic University & $1,401,269$ \\
\hline & Florida Gulf Coast University & $1,921,009$ \\
\hline & Florida International University & 537,315 \\
\hline & Florida State University & $1,827,855$ \\
& New College of Florida & $3,183,908$ \\
\hline & University of Central Florida & 229,918 \\
& University of Florida & $2,103,566$ \\
\hline & University of North Florida & $5,527,236$ \\
\hline & University of South Florida & 789,645 \\
\hline & University of West Florida & $2,524,802$ \\
\hline & 904,424 \\
\hline
\end{tabular}

Staffing and training. As the economic recession continues, staff are asked to take on more responsibilities and to spread themselves more thinly. Creating workflows and procedures within ILLiad that allow staff to save time can also mean providing patrons with access to materials longer in order to avoid excessive interface with an ILL system, creating a win-win scenario. By extending the loan period to 60 days with no renewal and still offering the ability to recall items, staff time is saved from processing renewal requests on both the lending and borrowing sides.

In Mary Jackson's book, "Assessing ILL/DD services: new cost-effective alternatives", the mean cost of a User-initiated interlibrary loan request in Borrowing is $\$ 2.39-\$ 14.70$ while the mediated ILL/DD cost for Borrowing was $\$ 17.50$. The Lending Unit cost of user-initiated ILL/DD was $\$ 3.27-\$ 12.06$ and mediated ILL/DD was $\$ 9.27$ (Jackson, 2004, Pernot, 2007). The combined borrowing/lending cost in 2004 for userinitiated ILL/DD was $\$ 6.16-\$ 26.76$, which offered a large range of saving opportunity when compared to the mediated ILL/DD cost of $\$ 26.77$, illustrating the great cost of staff time involved in each interlibrary loan request. Any amount of this time that can be circumvented, then, is only a benefit.

Shipping and receiving. In Florida, there is statewide courier system called Delivery. All libraries involved in the discussion about the UBorrow project receive daily Delivery service with the exception of one institution that does not receive service on Friday. Depending upon where the book is travelling, an item can arrive between 1 and 9 days after it is shipped from the lending library (UBorrow Implementation Team, 2012). The closer the item, the less the patron's due date is impacted by travel time and the patron can have the book for a longer loan period. If the requested item must travel from either end of the state, namely Miami or Pensacola, the book needs to travel nearly 727 miles and may take anywhere from 6-9 days. This information lead UBorrow developers to program an automatic padding of 7 days to ensure the advertised 30 day loan. This padding is not usually included in any Interlibrary Loan traffic. In a random sample of 25 returnable requests that were routed from University of West Florida to the University of Central Florida between January 1, 2011 and November 22, 2011, the average shipping period was 7.68 days. Items traveling from Salt Lake City, Utah to Orlando took on average 9.5 days. Items that traveled from within 120 miles took on average 3.5 days. When the Borrowing unit at the University of Central Florida received the returnable from the University of West Florida that was for a 30 day loan period, the book would already be 7.68 days into the 30 day loan period. The Borrowing unit would subtract 5 days for return shipping would mean the patron has an average loan period of 17.32 days if the item were picked it up the same day that the patron received 
the notification. A patron's time with the requested material is shortened further if it must be separated for any branch/regional processing which, at UCF, can be 30-60 miles extra travel. The patron then has the book on average less than 2 weeks. At Florida International University, the average loan period for a returnable to travel from Tallahassee, Florida to Miami was 6 days and from Raleigh Durham area to Miami took an average of 7.1 days with travel from College Station, Texas to Miami was 7.9 days.

If the average cost of mailing a library book via United State Postal Service is $\$ 4.00$ (Horton 2010 ), the question becomes one of money. How much money is being spent on borrowing the same title if a patron submits more than one request simply to buy time for adequate research? If the number of packages shipped between institutions can be lessened because the length of due date is more in line with researchers' needs how much money and staff time could be potentially saved? The United States Post Office is looking at closing branches and processing centers in order to save millions of dollars (Freeman, 2011) If mail processing facilities are closing, and first class mail will take on average 2-3 days, media mail may become delayed more than it currently is.

\section{Observations}

The University of Central Florida Libraries made the move toward a 60 day loan period for interlibrary loan requests about seven years ago. When the department switched from 30 to 60 day loan period, the number of renewal requests, overdues and invoices dropped significantly on the lending side. Staff time that was devoted to processing these functions went from 15-20 hours a week to less than 1 hour a week.

Florida A\&M University switched from a 30 day loan period to a 60 day loan period in July 2011 and the department has also seen a drop in overdues, invoices and renewal requests. Staff at both institutions were freed to devote their time toward the perfection of the general workflow of receiving a request and processing the request quickly without distraction.

The University of South Florida discovered that while Florida A\&M University had a 30 day loan period in 2010-2011, approximately 13\% of all returnables loaned to USF from FAMU were overdue. After Florida A\&M University changed their loan period from 30 days to 60 days, only $2 \%$ of those returnables were overdue.

Center for Research Libraries has a 3 month loan period for member libraries. A random sampling of 10 requests from five different institutions in Florida showed that the loan periods ranged from 33.7 days, 29.3 days, 47.9 days, 46.4 days and 80 days.

The reasoning for moving all resource sharing activity to a 60 day loan period was that it encapsulated the 4 week loan period, a 3 week renewal period and 11 days for shipping items back and forth between institutions. At the University of Central Florida, shipping and receiving of UPS and United States Postal Services is handled out of a central receiving department. Items may take a few days to be processed upon leaving the library. An extended loan period minimizes the effect this delay has on the end patron. Time is also built in to compensate for the longer process of international lending of materials and sending items further throughout the country. 
In the meantime, patrons have developed their own methods of handling shorter due dates on materials obtained through resource sharing services. A phenomenon noticed by staff at the University of Central Florida libraries is that patrons borrow items via interlibrary loan and, if the book has a short deadline, return the book while immediately submitting another request for the same title. Between July 1, 2010 and July 1, 2011, of the 20,300 borrowing requests submitted to UCF, patrons submitted resubmitted 364 requests for the same title at least once if not twice, indicating that patrons need the book longer than the 30 days.

\section{Conclusions}

A unified loan period for both ILL and consortial borrowing systems is good in theory. All patrons would receive the same loan period from the institutions that borrow and lend heavily amongst each other. This would help answer the question "how long can I have the book for" when patrons submit an ILL request. Staff members would know what to expect when borrowing from each other. Staff may not "pick their favorite" institutions, those that have 60 day loan period versus 30 days and may start to request items more evenly among all the institutions.

When the discussion began among the SULs, some interlibrary loan departments were enthusiastic about the idea of a 60 day loan period, others had concerns. The primary concerns have revolved around the inequality of circulation loan periods versus interlibrary loan due dates. Undergraduates among the libraries have a 3-4 week loan period compared to interlibrary loans that would be lent potentially for 60 or 90 days (if renewed). Would it be fair to the undergraduate that a book from their home institution may be going to another undergraduate in a different library for longer than they would have received it? Perhaps, as the University of South Florida decided, undergraduate loan times should be lengthened as well to align with group resource sharing and also encourage the use of the collection in light of falling circulation statistics. Those that argue for the 60 days feel that a long loan period is justifiable because of the extra work and labor that is involved in transporting the book between institutions. They postulate that a book checked out at the home institution can be renewed numerous times without staff intervention and thus balances the playing field. Even if circulation policies remain static, a 60 day loan period can also be viewed as equal to that of an undergraduate loan period of 4 weeks, plus a 3 week renewal and delivery time. Standardization of interlibrary loan dates to 60 days would benefit our users and streamline ILL processing. 
Bibliography:

Al-Fares, Hesham K. 1998. Optimizing a library's loan policy: an integer programming approach. Journal of the American Society for Information Science. 49(13) 1169-1176.

Ajayi N.A. and A.A. Okunlola. 2005. Students' perception of fine increases for overdue library books in an academic library. Journal of Librarianship and Information Science 37(4) 187-192.

American Library Association. 2012. Interlibrary Loan Code for the United States. http://www.ala.org/rusa/resources/guidelines/interlibrary.

Beaubien, Anne K. Jennifer Kuehn, Barbara Smolow and Suzanne M. Ward. 2006. Challenges facing highvolume interlibrary loan operations: baseline data and trends in the $\mathrm{ClC}$ consortium. College \& Research Libraries. 67(1) 63-84.

Burrell, Quentin L. and Michael R. Fenton. 1994. A model for library book circulations incorporating loan periods. Journal of the American Society for Information Science. 45(2) 101-116.

Farrington, Jean Walter. 1984. "Overdues and Academic Libraries: Matters of Access and Collection Control." Library \& Archival Security. 667-75.

Florida Center for Library Automation. 2012. Overview. Retrieved from http://fclaweb.fcla.edu/reports_statistics

Freeman, Joseph. U.S. Postal Service may close 8 Central Florida post offices. Orlando Sentinel, July 26, 2011. http://articles.orlandosentinel.com/2011-07-26/features/os-florida-post-offices-closing201107261 post-offices-postal-service-plant-street.

Goehlert, Robert. 1979. The effect of Ioan policies on circulation recalls. 1979. The Journal of Academic Librarianship. 5(2) 79-82.

Gregory, David J. and Wayne A. Pedersen. 2003. Book availability revisited: turnaround time for recalls versus interlibrary loans. College \& Research Libraries. 64(4) 283-299.

Hallyburton, Ann W., Heidi E. Buchanan and Timothy V. Carstens. 2011. Serving the whole person: popular materials in academic libraries. 30(2) 109-112.

Harris, Karen and Elleene Morgan. 1999. "Let the Students decide." Library Journal. 124(16) 67-68.

Henderson, Albert. 2000. The library collection failure quotient: the ratio of interlibrary borrowing to collection size. The Journal of Academic Librarianship. 26(3) 159-170. 
Horton, Valerie, Susan Burton, Franca Rosen and Lisa Priebe. 2010. COKAMO: a model for fast, inexpensive interstate delivery. Collaborative Librarianship. 2(4) 218-224.

Jackson, Mary E. Assessing ILL/DD services: new cost-effective alternatives. Association of Research Libraries. 2004.

Leung, Yau Ching. 2005. User education on circulation policies. Journal of Access Services. 3(1) 37-46.

McHone-Chase, Sarah M. 2010. Examining change within interlibrary loan. Journal of Interlibrary Loan, Document Delivery \& Electronic Reserve. 20(3) 201-206.

Meyers, Elaine. 1999. The Coolness factor: Ten Libraries Listen to Youth. American Libraries. November 1999. 30(10) 42-45.

Pernot, Eli, Filip Roodhooft and Alexandra Van den Abbeele. 2007. Time-driven activity-based costing for inter-library services: a case study in a university. The Journal of Academic Librarianship. 33(5) 551-560.

Rogers, Michael. 1999. Loans \& groans. Library Journal. 124(16) 67-68.

Rupp, Eric, Kimberly Sweetman and David Perry. 2010. Updating circulation policy for the $21^{\text {st }}$ century. Journal of Access Services. 7(3) 159-175.

Salaam, M. O. 2004. The treatment of other libraries' books by Nigerian University Libraries. Library \& Archival Security. 19(1) 47-52.

Saracevic T., W.M. Shaw, jr. and P.B. Kantor. 1977. Causes and dynamics of userfrustration in an academic library. College \& Research Libraries. 38(1) 7-18.

Sweet, Christopher A. 2009. Increasing efficiency and decreasing waste by overhauling interlibrary loan procedures at a small community college. Journal of Interlibrary Loan, Document Delivery \& Electronic Reserves. 19(2) 155-164.

UBorrow Implementation Team. (2012) Update on Ground Delivery Assessment. (unpublished report). 